\title{
China's Foreign Aid
}

- History, Current Situation and Challenges -

Tang Lixia $\cdot$ Ma Jiewen $\cdot$ Li Xiaoyun1)

(College of Humanities and Development Studies, China Agricultural University)

\section{Contents}

I. History and Strategic Evolution of China's Foreign Aid

II. China's Foreign Aid Funds, Scale, Method, Key Areas and Direction

1. Funds and Scale of Aid

2. Aid Sectors

3. Distribution of Aid

III. China's Foreign Aid Agencies and Management

IV. Challenges for China's Foreign Aid

Abstract: Over the years, while focusing on its own development, China has been providing aid within its capacity to other developing countries with economic difficulties, and fulfilling its due international obligations. This paper attempts to make a systematic

1) Correspondent author 
introduction and review of China's foreign aid from an historical and policy perspective, including scale, methods, fieldwork, and, management experiences as practical challenges. As an important external field of China's own development experience, China's foreign aid has actively supported the political independence, economic development and social progress of developing countries, made a significant contribution to the realization of China's international strategic objectives in different periods and set a good example for "South-South cooperation". It is a useful supplement to the traditional Western aid architecture. Meanwhile, there is still the need to enhance the level of intellectual debate around China's foreign aid policies, to continue to make innovations to the foreign aid mode, to optimize the assistance structure, and actively engage in effective dialogue with Western countries to cope with increasingly severe international challenges.

Key words: China's foreign aid, South-South Cooperation, Mutual benefit

In 1950, China provided material assistance to Vietnam and the Democratic People's Republic of Korea, opening the prelude of China's foreign aid. Since then, while focusing on its own development, China has continuously always been providing aid to other developing countries. From political and diplomatic purpose-driven unilateral aid to the mutually beneficial economic cooperation, China's foreign aid modalities established under the framework of South-South Cooperation are significantly different from traditional main aid modalities of Western countries' main aid modalities (Wang \& Ozanne, 2010). Various forms of funding, multi-field coverage, a variety of aid modalities and a three-dimensional full range of aid management constitute the aid mode with Chinese characteristics. China's foreign aid projects have received widespread recognition and praise from the recipient countries, becoming a useful supplement to the traditional aid architecture (Li, 2013). This paper attempts to makes a systematic introduction and review of China's foreign aid system and to contributes respond to the international discussion on China's foreign aid. 


\section{I . History and Strategic Evolution of China's Foreign Aid}

When talking about China in the field of foreign aid, the international community often uses the term "emerging donor" to show that China is a "rising star" in the field of foreign aid (Woods, 2008; McCormick, 2008). In fact, however, China started its foreign aid to other developing countries almost at the same time as the Western countries (Li, 2013). Since it provided material assistance to the Democratic People's Republic of Korea and Vietnam in the 1950s, China has continued its foreign aid work for more than six decades. According to the characteristics of the development aid and and the subsequent changes, the history of China's foreign aid can be roughly divided into three stages.

The first stage is the period from the founding of New China to the reform and opening up, i.e. the start-up stage of China's foreign aid. After the Asian-African Conference held in Bandung in 1955, the objects of China's foreign aid extended from neighboring countries to other developing countries, especially to Africa, for which China mainly provided economic and technical assistance and military aid. The construction of Tanzania-Zambia Railway became a landmark event in China's foreign aid. Although the Chinese government announced the Eight Principles for Economic Aid and Technical Assistance to Other Countries with "equality and mutual benefit, without any attached conditions" as the core principles in 1964, the policy at this stage was still at the exploratory stage, being mainly manifested by prominent unidirectional features. China seldom received any aid from other countries and its foreign aid was provided mainly for political and diplomatic interests (Zhang, 2009). The aid decision-making put great emphasis on ideological factors, not taking into account such factors as economic feasibility, so the aid scale expanded sharply and the aid fund amount exceeded China's economic capacity (Li, 2013). From 1971 to 1978, China provided foreign aid of 29.66 billion Yuan to a total of 68 recipient countries, and this figure rose to 5.58 billion Yuan in 1973 accounting for $7.2 \%$ of China's fiscal expenditure, exceeding the proportion of foreign economic aid of the world's most developed and richest countries (Zhang, 2009). 
The second stage is the period from late 1980s to mid-1990s, i.e. the Adjustment Stage of China's foreign aid. In this stage, China highlighted the basic principle of "equality", and the economic significance of foreign aid went beyond the demands of political interests. It put more emphasis on improving the economic efficiency and long-term effects of aid projects, striving to form a mutually beneficial win-win situation for mutual development with developing countries. Meanwhile, with the transformation of domestic planned economy to a socialist market economic system, the aid quality, efficiency and sustainability and other economic rationality factors were covered by the aid decision-making system. On the other hand, based on China's economic strength and actual situation, "remaining realistic while striving for the best" became the main guiding spirit for foreign aid in this stage. China did not significantly increase the amount of foreign aid and the foreign aid spending only accounted for $0.09 \%$ of the GNP. China was no longer a single donor, but had the double identity of "donor recipient country" and began to accept assistance from international organizations and developed countries.

After the mid-1990s, with the enhancement of China's economic strength and the formation of its diplomatic strategy emphasizing "mutually beneficial cooperation and common development", as a non-traditional donor, China gradually attracted international attention and China's foreign aid thus entered into the third stage of comprehensive advancement. First of all, at this stage, China's foreign aid content and methods became diverse and as for the aid channels, China attached increasing importance to strengthening the collective consultation with recipient countries. The specific aid modalities included eight methods developed in various stages. Secondly, aid funds showed a linear upward trend, and the average annual growth rate of foreign aid from 2004 to 2009 was 29.4\%. On the whole institutionalization and standardization became the focus of China's foreign aid work in this period. The institutionalized Forum on China-Africa Cooperation has become a primary mechanism for China to provide economic and technical assistance to Africa, and a series of action plans developed at the forum have become the program guidelines for China's assistance to Africa. 
〈Table 1〉 Three phases of Chinese Foreign Aid, 1953-2012

\begin{tabular}{c|c|c|c|c|c|c}
\hline Phase & Year & $\begin{array}{c}\text { Foreign } \\
\text { Aid (100 } \\
\text { Million) }\end{array}$ & $\begin{array}{c}\text { Total } \\
\text { Financial } \\
\text { Expenditure } \\
\text { (100 Million) }\end{array}$ & $\begin{array}{c}\text { Percentage } \\
\text { of foreign } \\
\text { aid in foreign } \\
\text { expenditure }\end{array}$ & $\begin{array}{c}\text { GNP } \\
\text { (100 } \\
\text { Million) }\end{array}$ & $\begin{array}{c}\text { Percentage } \\
\text { of foreign } \\
\text { aid in GNP }\end{array}$ \\
\hline I & $1953-1978$ & 18.49 & 536.34 & $3.45 \%$ & 1869.77 & $0.99 \%$ \\
\hline$I I$ & $1979-2000$ & 20.01 & 4740.47 & $0.42 \%$ & 32901.32 & $0.06 \%$ \\
\hline III & $2001-2012$ & 99.95 & 56829.48 & $0.18 \%$ & 269368.76 & $0.04 \%$ \\
\hline
\end{tabular}

Source: Chinese Statistics Year Book (various years), China Statistics Press

In 2011, China published the first "White Paper on Foreign Aid", marking the development of China's foreign aid policy towards openness and transparency. As a result, China's foreign aid system with the features of the three-dimensional and integrated features of China's foreign aid system becomes increasingly prominent and is becoming an integral part of Chinese symbols. In addition, China began to provide foreign aid within the framework and system of the international community, actively participating in the UN High-level Conference on the Millennium Development Goals and delivering aid commitments to developing countries. It gradually diluted its identity as a recipient country. A growing number of bilateral and multilateral development agencies have changed their unidirectional aid relationship with China to a more extensive cooperative arrangement.

\section{China's Foreign Aid Funds, Scale, Method, Key Areas and Direction}

\section{Funds and Scale of Aid}

Financial resources provided by China for foreign aid mainly fall into three types: aid grants, interest-free loans and concessional loans. Grants are mainly used to help recipient countries to build hospitals, schools and low-cost houses, and support well-digging or water-supply projects, and other medium and small projects for social 
welfare. Interest-free loans are mainly used to help recipient countries to construct public facilities and launch projects to improve people's livelihood. The tenure of such loans is usually 20 years, including five years of use, five years of grace and ten years of repayment. Concessional loans are mainly used to help recipient countries to undertake productive projects generating both economic and social benefits and large and medium-sized infrastructure projects, or to provide complete plant, mechanical and electrical products, technical services and other materials. At present, the annual interest rate of China's concessional loans is between $2 \%$ and $3 \%$, and the period of repayment is usually 15 to 20 years (including five to seven years of grace)(white paper, 2011).

The first two come from China's state finances, while concessional loans are provided by the Export-Import Bank of China as designated by the Chinese government (China's Foreign Aid, 2011). At present, the annual interest rate of China's concessional loans is between $2 \%$ and $3 \%$, and the period of repayment is usually 15 to 20 years. In addition to the above mentioned types of funds, other foreign aid financial arrangements include preferential buyer's credit, China-Africa development funds and African SME development loans, etc. Compared to developed Western countries, in recent years, China has increased the proportion of concessional loans. In 2010 and 2011, China provided 63.36 Billion yuan of foreign aid funds, of which 23.92 Billion yuan was in grants, 9.7 billion Yuan was in interest-free loans and 29.74 billion Yuan was in concessional loans, respectively accounting for $37.75 \%, 15.31 \%$ and $46.94 \%$ of the total. At the same time, OECD-DAC countries provided 221.436 billion U.S. dollars, including grants of $\$ 181.336$ billion, accounting for $81.89 \%$ of the total, and concessional loans of 36.189 billion U.S. dollars, accounting for only $16.34 \%$ of the total.

〈Table 2〉 The structure of foreign aid funds: China and DAC

\begin{tabular}{c|c|c|c|c|c|c}
\hline \multirow{2}{*}{} & \multicolumn{2}{|c|}{ Grant } & \multicolumn{2}{c|}{ Loan } & \multicolumn{2}{c}{ Other } \\
\cline { 2 - 7 } & Amount & $\%$ & Amount & $\%$ & Amount & $\%$ \\
\hline $\begin{array}{c}\text { China } \\
\text { (billion yuan) }\end{array}$ & 23.92 & $37.75 \%$ & 39.44 & $62.25 \% \%$ & - & - \\
\hline $\begin{array}{c}\text { DAC member } \\
\text { (billion USD) }\end{array}$ & 181.336 & $81.89 \%$ & 36.189 & $16.34 \%$ & 3.911 & $1.77 \%$ \\
\hline
\end{tabular}

Source: MOFCOM and http://stats.oecd.org/index.aspx 
China does not report to the OECD-DAC its foreign aid data and its official statistical caliber for foreign aid is significantly different from that of DAC (Zhang, 2011). For example, debt relief and scholarships are not covered in the scope of China's official development assistance, but are included in the Western aid statistics. Another example, China's preferential loan assistance only calculates the interest subsidy to the Export-Import Bank of China, but DAC countries take into account the full amount of the preferential loan. In addition, China's foreign aid budget usually includes military assistance and the loans provided for foreign-aided joint ventures and cooperative projects (Brautigam, 2009), which clearly are not taken into account by the ODA. Therefore, the international community has become concerned about the scale of China's foreign aid and some scholars have made their own estimates. For example, some estimate that China's annual development assistance fund may have reached $\$$ 1.5-2 billion (Lancaster, 2007b). Seen from the perspective of scale, however, compared to the developed countries, the amount of China's aid is still relatively small (Liu, 2011).

In addition, the concern about the scale of China's foreign aid has also resulted from the change in the balance of two forces for international assistance. In accordance with the DAC (2012) statistics, in 2011, the total amount of ODA provided by all the DAC members dropped by $2.7 \%$ compared to that of 2010, and the net expenditure of other official capital flows also decreased by $50 \%$ compared to that in 2009. According to the DAC's forecasts, this downward trend will continue. Since 2000, however, the total amount of China's foreign aid funds has maintained rapid growth with the average annual growth rate from 2004 to 2009 being 29.4\%. In 2012, the foreign aid fund announced by the Chinese government nearly tripled that of 2004. In addition, the concern about the scale of China's foreign aid is also a result of the high fulfillment rate of China's foreign assistance commitments. According to the OECD / DAC statistics, the DAC member countries' aid commitment fulfillment rate has remained at about $90 \%$ in recent years, but this figure in China exceeded 95\% in accordance with the central expenditure budget and final budget implementation report of the Ministry of Finance of PRC, and even exceeded the budget in some years. 
〈Table 3〉 The aid commitment and disbursement: China and DAC members

\begin{tabular}{c|c|c|c|c}
\hline & 2007 & 2008 & 2009 & 2010 \\
\hline DAC members & $92.77 \%$ & $86.63 \%$ & $87.00 \%$ & $90.25 \%$ \\
\hline China & $103.40 \%$ & $97.70 \%$ & $95.70 \%$ & $102.40 \%$ \\
\hline
\end{tabular}

Source: China Years Statistics and http://stats.oecd.org/index.aspx?

From the perspective of aid modalities, China started foreign aid by providing goods and materials, which later increased to complete project aid, including technical cooperation, human resources development cooperation and foreign aid medical teams. Today, these five conventional aid modalities still occupy an important position in China's foreign aid provision. Since the 1990s, China conducted a series of reforms to promote the diversification of forms of assistance, and gradually increased the aid modalities, such as emergency humanitarian aid, volunteer programs in foreign countries, and debt relief. It significantly increased efforts on debt relief. At of the end of 2011, China had signed debt relief protocols with 50 countries from Africa, Asia, Latin America, the Caribbean and Oceania, cancelling 391 mature debts totaling 27.56 billion Yuan.

The aid modalities of technical cooperation, human resources development cooperation, medical teams sent abroad, emergency humanitarian aid, volunteer programs in foreign countries and debt relief have all been adopted by OECD-DAC member countries and China. Project assistance has also been adopted by DAC members and China. The difference is that OECD -DAC members also provide two other aid modalities, namely budget support and program support, which both provide aid funds directly to the recipient countries / regions, with the funds being used by relevant departments of the recipient countries / regions. Such funds account for about $20 \%$ of the total aid budget. China's foreign aid, however, is mainly project assistance, and the aid projects are mainly constructed under the leadership of relevant Chinese companies (Brautigam, 2011). The aid funds are seldom transferred directly to the recipient countries / regions. That is the often quoted "turnkey" project. Although China's official documents never mention budgetary assistance and program assistance, prominent researchers have found that China actually provides limited budgetary aid. In 2004, for example, 
China provided $\$ 3$ million to Liberia to support the operation of power-sharing transitional government for 100 days; in 2006, China again provided the country with $\$ 1.5$ million of budget support. The Chinese government provided $\$ 4$ million to Guinea-Bissau for the payment of salaries of civil servants in 2004, provided $\$ 1.5$ million of international balance of payment support to Seychelles in 2007, and provided $\$ 5$ million in cash for Zimbabwe to pay wages in 2009 (Brautigam, 2012). The budgetary aid fund provided by the Chinese government in cash is sporadic and temporary rather than continuous and regular, and the purpose is very clear, and is quite different from the budgetary aid advocated by the United Kingdom and other countries.

\section{Aid Sectors}

According to official statistics, China's foreign aid covers agriculture, industry, economic infrastructure, public facilities, education, medical and health care as well as the newly proposed climate change assistance including cleaning energy as solar using and biogas. Although the announced development aid data do not divide the areas of investment and detailed figures cannot be obtained, there is no doubt that China has put substantial aid resources into the field of infrastructure, which the Western countries are unwilling to invest in. It is however an urgent need in many developing countries (Lancaster, 2007). China's economic infrastructure support is very significant. Sixty One per cent of the preferential loans and $20 \%$ of the complete projects fall under economic infrastructure, while the Western developed countries invest little in this field, instead, they invest more in social public infrastructure and services. In 2010, the international funds invested in this field accounted for 30\% of the total. China, however, invests little in the social and services field. Different from the Western countries, China attaches importance to assistance in the agricultural sector. China's agricultural aid modalities are diverse, including the construction of farms, agricultural technology demonstration centers, agricultural technology experimental stations and promotion stations, rehabilitation of farmland and water conservancy projects, provision of farm machinery, agro-processing equipment and related 
agricultural supplies, dispatch of agricultural technicians and senior agricultural experts to teach agricultural production techniques, provide agricultural development consulting services and organize training of agricultural personnel in recipient countries, etc. Agricultural assistance accounts for $4.7 \%$ of China's foreign preferential loans and $10.62 \%$ of the completed projects. The Western countries, however, provide relatively less aid in agriculture. In addition, China seldom provides development assistance to non-governmental organizations (NGOs), and no such information has been released so far. The Western countries, however, attach importance to the development of NGOs. From 2001 to 2007, they provided a total of $\$ 11$ million of aid funds to NGOs.

\section{Distribution of Aid}

From the perspective of geographical distribution, China's foreign aid shows the feature of comparatively even coverage. The recipients cover most developing countries in Asia, Africa, Latin America, the Caribbean, Oceania and Eastern Europe. As of the end of 2009, China had aided 161 countries and more than 30 international and regional organizations, including 123 developing countries that received aid from China on a regular basis. Of them, 30 are in Asia, 51 in Africa, 18 in Latin America and the Caribbean, 12 in Oceania and 12 in Eastern Europe. Asia and Africa, home to the largest population of poor people, received about $80 \%$ of China's foreign aid. Seen from the distribution of aid, there is no significant difference between the development assistance of China and Western countries. Seen from the geographical distribution, Africa and Asia are both key areas for the development assistance of China and Western countries. China pays more attention to aid to Africa and provides little aid to Europe. Comparatively speaking, China also attaches importance to aid to Latin America. Seen from the conditions for economic development of the recipient countries, China and the Western countries both target LDCs in providing assistance. Comparatively speaking, China is more inclined to provide assistance to low-income countries, while the Western countries put more emphasis on aiding low-and middle-income countries. 
〈Table 4〉 Comparison of the proportion of foreign aid regions of China and DAC member countries in 2009

\begin{tabular}{l|r|r|r|r|r|r}
\hline & Europe & \multicolumn{1}{|c|}{ Africa } & Latin America & \multicolumn{1}{c|}{ Asia } & Oceanica & Unspecified \\
\hline China & $0.30 \%$ & $45.70 \%$ & $12.70 \%$ & $32.80 \%$ & $4 \%$ & $4.50 \%$ \\
\hline $\begin{array}{l}\text { DAC member } \\
\text { countries }\end{array}$ & $3.60 \%$ & $31.62 \%$ & $7.74 \%$ & $32.64 \%$ & $1.64 \%$ & $22.76 \%$ \\
\hline LDCs & $\begin{array}{l}\text { Low-income } \\
\text { countries }\end{array}$ & $\begin{array}{l}\text { Low-and } \\
\text { middle- } \\
\text { income } \\
\text { countries }\end{array}$ & $\begin{array}{l}\text { High-and } \\
\text { middle- } \\
\text { income } \\
\text { countries }\end{array}$ & $\begin{array}{l}\text { Other } \\
\text { unspecified }\end{array}$ & \\
\hline $\begin{array}{l}\text { China } \\
\text { DAC member } \\
\text { countries }\end{array}$ & $39.70 \%$ & $23.40 \%$ & $19.90 \%$ & $11.00 \%$ & $6 \%$ & \\
\hline
\end{tabular}

Source: Ministry of Commerce: "China's Foreign Aid" (White Paper), 2011; OECD website:

http://stats. oecd.org/index.aspx?

\section{China's Foreign Aid Agencies and Management}

With the development of external relations and foreign aid work, China has gradually set up and improved relevant agencies at all levels to manage its foreign aid and has constantly increased project management efforts (Ministry of Commerce, 2011). The characteristics can be summarized as centralized control and integrated management (Zhang, 2012). China has not set up a special and independent agency to facilitate foreign aid provisions like the developed countries in the West In China, the aid fund has been increased quickly. China's foreign aid coordination is under the responsibility of the State Council. As China's highest administrative organ, however, the State Council can hardly conduct specific coordination and management of the foreign aid affairs, so the Ministry of Commerce plays a key role in foreign aid management and is responsible for the formulation of foreign aid policy, regulations, overall planning and annual plans, the review and approval of various kinds of aid projects and the whole process and management of project delivery (Ministry of Commerce, 2011), and needs to manage and coordinate nearly $90 \%$ of China's foreign aid capital. More than 20 ministries including Ministry of Foreign Affairs and the Ministry of Finance, 
Ministry of Agriculture, and Ministry of Health are involved in the administration and implementation of foreign aid. The inter-ministry cooperation has become a key focus of foreign aid administration. China has set up a mechanism for a leading group for foreign aid, a mechanism for inter-ministry communication, and a mechanism of inter-ministry coordination to promote the facilitation of aid projects by the different ministries.

As the main governing body of foreign aid, the Ministry of Commerce specially created the Department of Aid to Foreign Countries (DAFC) to be specifically responsible for the management of foreign aid affairs. It also set up three institutions to support its aid work management, namely the Executive Bureau of International Economic Cooperation (EBIEC), China International Center for Economic \& Technical Exchange and the Training Center of the Ministry of Commerce. The Executive Bureau of International Economic Cooperation is mainly responsible for the implementation and management of complete aid projects and technical cooperation projects. The China International Center for Economic \& Technical Exchange is responsible for the implementation and management of foreign aid material projects. The Training Center under the Ministry of Commerce is mainly responsible for management and comprehensive coordination of foreign aid training projects. Under the supervision of the Department of Aid to Foreign Countries, the above three departments are responsible for the organization and management of aid projects in the course of project construction, including bidding and project implementation organization and management. Moreover, the MOH is responsible for overseas medical teams, the CCYI for overseas volunteers and MOF is in charge of emergent humanitarian aid. Concessional loans are under the management of the Export-Import Bank of China. The financial resource for all above aid modalities will be accounted for under the item of Foreign Aid Expenditure of the Central Budget System, except concessional loans. Furthermore, the departments of international cooperation under most ministries, such as MOA, MOST, MOE can also offer international aid from their own financial budget. The fragmented administrative system creates the problem of foreign aid statistics being inconsistent and administratively costly to maintain. 
〈Table 5〉 Role of the Overseas Economic \& Commercial Office in the management of various agricultural aid projects

\begin{tabular}{|c|c|}
\hline Aid modalities & $\begin{array}{l}\text { Management responsibilities of the Overseas Economic \& } \\
\text { Commercial Office }\end{array}$ \\
\hline $\begin{array}{l}\text { Construction phase of } \\
\text { the agricultural } \\
\text { technology } \\
\text { demonstration centers }\end{array}$ & $\begin{array}{l}\text { Demonstration center construction monitoring, helping resolve } \\
\text { the difficulties in the process of project implementation and } \\
\text { handling the intergovernmental transfers with relevant } \\
\text { government departments of the recipient country }\end{array}$ \\
\hline $\begin{array}{l}\text { Technical cooperation } \\
\text { stage of the } \\
\text { agricultural } \\
\text { technology } \\
\text { demonstration centers }\end{array}$ & $\begin{array}{l}\text { Management of the technical cooperation activities of the } \\
\text { demonstration centers, especially the filing and registration } \\
\text { of working staff as well as the briefing finishing }\end{array}$ \\
\hline of & Coordination of the technical services of agricultural experts \\
\hline $\begin{array}{l}\text { Agricultural material } \\
\text { assistance }\end{array}$ & $\begin{array}{l}\text { FAMP feasibility study, supplies supervision, exchanging the } \\
\text { list of supplies }\end{array}$ \\
\hline $\begin{array}{l}\text { Agricultural } \\
\text { technology training }\end{array}$ & $\begin{array}{l}\text { Conduct research of the training needs of the recipient country, } \\
\text { explore foreign aid training mode suitable for the recipient } \\
\text { country and put forward specific suggestions, assist in student } \\
\text { enrollment, assist relevant domestic department to order } \\
\text { round-trip international airline tickets and conduct return visits } \\
\text { to the trainees }\end{array}$ \\
\hline
\end{tabular}

Source: Based on various project management regulations of the Ministry of Commerce and the interviews with key informants of the Overseas Economic \& Commercial Office in the Zimbabwe

One of the important differences between Chinese foreign aid management and traditional Western donor countries' aid management is the foreign aid management mechanism in the recipient country. The Western countries usually set up specialized assistance management institutions in the recipient country for the coordination of their aid activities in the country. China's foreign aid is under the leadership of the Ministry of Commerce. As it also undertakes other non-aid affairs, the Ministry of Commerce has not set up specialized foreign aid management agency. In the recipient country, therefore, China has not set up specialized institution for foreign aid management. The Overseas Economic \& Commercial Office of the Ministry of Commerce 
is responsible for the coordination as well as the agricultural aid activity coordination and management in the recipient country. Its main functions include: 1) Project approval, understand the assistance needs of recipient countries through holding seminars or conducting research and form the initial project application. 2) Assist in signing project agreement, establish the contract and signing the implementation contract; 3) Coordinate the handover of the assistance projects; 4) Coordinate and organize the implementation work briefings of the project construction unit. In addition, for different aid projects, the Overseas Economic \& Commercial Office will provide different management services. Just like the Ministry of Commerce, the Overseas Economic \& Commercial Office assumes many responsibilities and can hardly spare many staffs and a lot of time on the coordination and management of foreign aid affairs, so it is hard for the Overseas Economic \& Commercial Office to play a role.

\section{Challenges for China's Foreign Aid}

Since the 1950s, China has been providing aid to other developing countries within its capacity and established its aid system and mode different from the traditional Western donors under the framework of South-South Cooperation, with an increasing influence in the field of international development. The "mutually beneficial and win-win situation in the South-South cooperation" advocated by China was recommended by Manning, former chairman of DAC as a goal of the Post-2015 Development Framework $(\mathrm{Xu}, 2013)$. In the construction of the new round of international discourse, China's voice has attracted unprecedented attention. China's foreign aid, however, is also facing challenges from the international community. Commentators have made thinly veiled criticisms of China's foreign aid as it does not obey the common aid rules established and followed by the Western countries. Neo-colonialism, energy plunder and even land grabbing are often used in criticizing China. In fact, the Western countries' controversies about China's foreign aid, especially aid to Africa indicate that they are concerned that China's involvement in aid to Africa will become a challenge and even a threat for their traditional interests, including threats to democracy, human 
rights, good governance values and a variety of business rules imposed by the Western countries on Africa over time (Chris Alden, China in Africa, Zed Books \& IAI, 2007, PP.102-110). China's foreign aid faces challenges from three aspects.

Firstly, in the face of rapidly growing scale of assistance, how can we improve the effectiveness and quality of aid? When the amount of aid is very limited, the province-based political mobilization method, the "turnkey" model and the aid method relying on the recipient countries' own ability, as adopted by China, can guarantee the quality of aid projects. The actual investment in aid project quality monitoring and evaluation is very limited, reducing the cost of China's aid. With the expansion of China's assistance scale, however, the lack of systematic and standardized aid quality monitoring and evaluation will become an increasing and prominent disadvantage. China is also going to learn from the experience of some development assistance projects of Western countries, but the high cost due to the implementation of the complex aid effectiveness monitoring system of the Western countries is also widely criticized. It will be the first challenge for China's foreign aid how to learn from the Western countries to improve the aid effectiveness monitoring and maintain "low cost" at the same time.

Secondly, facing the continuous development of the global multilateral cooperation framework, how can China better integrate into the multilateral development framework? Although China has established cooperative relationship with many international multilateral institutions, the cooperation mainly refers to the aid arrangements that those institutions have with China. In some cases, trust funds have been set up with a few agencies, but the number is very limited, and China's foreign aid is still mainly bilateral aid. Even the aid commitment to Africa under the multilateral mechanism of the Forum on China-Africa Cooperation is also realized through the bilateral mechanism. In the construction of the current international development system, China has also actively participated in the discussion of the Post-2015 Development Framework and even put forward and actively participated in the establishment of the BRIC Development Bank, the Asian Infrastructure Construction Bank and other multilateral mechanisms. For a long time, however, China 
has been absent in the multilateral cooperation mechanism. It is the second challenge as to whether China can understand quickly the international multilateral development discourse and its system and then participate and play its role in the system.

Thirdly, in the face of increasingly complex foreign aid affairs, how can China develop a professional team for development aid as soon as possible? For a long time, China's foreign development assistance relied on functional departments and project contracting agency's technical staff, not forming a foreign development assistance industry chain. The Western countries' development aid, however, has evolved its professional and specialized resources involving international political, economic, social, cultural, environmental and development programs, monitoring and evaluation as well as other different areas and aspects, laid the basis for academic training of foreign aid personnel and engaged effectively with think tanks. In China, there are now only a very small number of universities and research institutions that have set development aid-related curriculums and conducted the study of assistance that can have a dialogue with the Western discourse system. They will be hard pressed to provide intellectual support for China's foreign aid for the moment. On the one hand, China needs to learn from the experience of Western countries in training professional personnel and, on the other hand, it should consider how to avoid complete duplication of the Western method of "expert interventionism", which is the third challenge facing the development of China's foreign aid. 


\section{References}

1. Carol.Lancaster, "The Chinese Aid System", Center For Global Development Essay, 2007.

2. Carol.Lancaster, "Foreign Aid: Diplomacy, Development, Domestic politics", the University of Chicago Press, 2007b.

3. “China's African Policy”, Xinhuanet, http://news. xinhuanet.com/politics/2006-01/12/content 4042317.htm, January 12, 2006

4. Chris Alden, China in Africa, Zed Books\& IAI, 2007.

5. Dai Lunzhang, editor in chief, "China's Foreign Economic Relations Towards the 21st Century”, China Price Press, 1997

6. Deborah Br utigam. "China's Challenge to the International Aid Architecture," World Politics Review, v. 1, n. 4 July/August 2009.

7. Deborah Brautigam, translated by Shen Xiaolei, Gao Mingxiu, "Dragon's Gift: The Real Story of China in Africa”, Social Sciences Academic Press, 2012

8. Department of Aid to Foreign Countries, Ministry of Commerce, "Basic Situation of China's Foreign Aid",

http://yws.mofcom.gov.cn/article/m/policies/201205/20120508116616. shtml, 2012-05-10

9. Dorothy McCormick, "China and India as Africa's New Donors: Understanding the Impact of Aid on Development." Review of African Political Economy 35(1):73-92, 2008.

10. Editor in chief, Shi Lin, “Contemporary China's Foreign Economic Cooperation”, China Social Sciences Press, 1989

11. Huang Meibo, Renpei Qiang, "China's Foreign Aid: Policy Evolution and Future Trends", “International Economic Cooperation”, 2012, No. 3.

12. Liao Lan, Liu Jing, "Study of China's Foreign Aid in the Eye of the Western Countries", "Journal of China Agricultural University (Social Science)", December 2012

13. Liu Zhongwei, "Comparative Analysis of African Development Aid among International Scale”, “West-Asia and Africa”,2011.

14. Li Xiaoyun, Tang Lixia, Wu Jin, "Introduction to International Development Assistance", 
Social Sciences Academic Press, 2009.

15. Li Xiaoyun, "Can the Foreign Aid of China and the West Donors be Complementary in International Development?”, unpublished,2013.

16. Li Zhengping, Zhang Cuiwei, "Explore A New Way for Foreign Aid”, "Economic Daily", November 14, 1995

17. National Bureau of Statistics, “China Statistical Yearbook”, 1950 -2013.

18. Ngaire Woods, "Whose aid? Whose influence? China, emerging donors and the silent revolution in development assistance”, International Affairs (84:6), 2008.

19. OECD, http://stats. oecd.org/index.aspx.

20. OECD Glossary of Statistics Terms, http://stas.oecd.org/glossary/index.htm.

21. The Chinese Ministry of Foreign Economic Relations and Trade, "Yearbook of China's Foreign Trade \& Economic Cooperation (1994)”, China Society Press, 1995

22. The Ministry of Commerce, "China's Foreign Aid” (White Paper), 2011

23. Wen Jiabao: "Comprehensively promote China-Africa new strategic partnership Speech at the opening ceremony of the Fourth Ministerial Conference of FOCAC"

24. Xiaobing Wang, Adam Ozanne, "Two Approaches to Aid in Africa: China and the West", Prepared for the International Conference "Ten Years Of 'War Against Poverty':What Have We Learned Since 2000 And What Should We Do 2010-2020?" hosted by the Brooks World Poverty Institute, The University of Manchester, at Hulme Hall, 8-10 September 2010.

25. Xu Xiuli, If China can reconstructure the framework of international aid. Working paper, 2013

26. Zhang Qingmin, “From the 'nationalism' to the 'mutual benefits': the change to the policy of China's foreign aid”, “Motherland”, 2010.

27. Zhang Xinghui, “China's Aid to Africa: Challenges for the EU?”, quoted from the Door Mirrors, [UK] Benjamin • Barton, editor in chief, translated by Li Jingkun, "China and the European Union in Africa - African Factor in EU-China Relationship”, Social Sciences Academic Press, 2011.

28. Zhang Yongpeng, "International Development Cooperation and Africa - Comparative Study of the Aid to Africa Provided by China and Western Countries”, Social Sciences Academic Press, 2013. 